
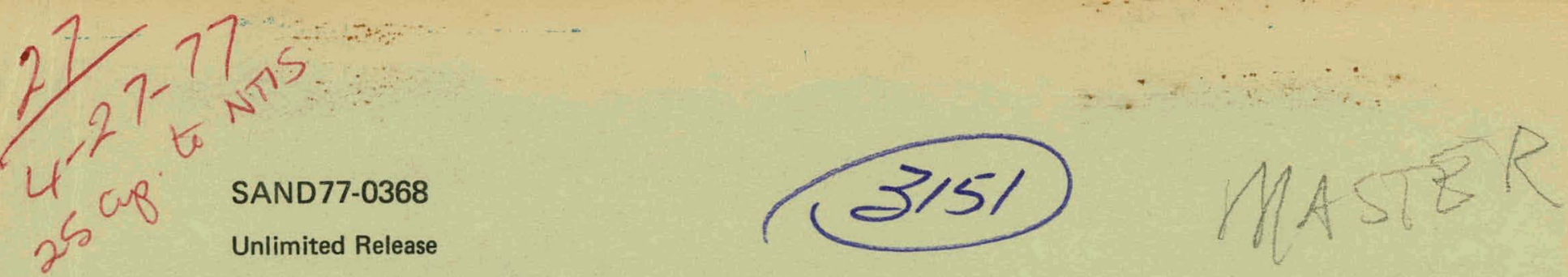

\title{
Substrate Cleaning Prior to Thick Film Screening
}

Gerrit J. Hof

Prepared by Sandia Laboratories, Albuquerque New Mexico 87115 and Livermore, California 94550 for the United States Energy Research and Development Administration under Contract AT (29-1)-789

Printed April 1977 


\section{DISCLAIMER}

This report was prepared as an account of work sponsored by an agency of the United States Government. Neither the United States Government nor any agency Thereof, nor any of their employees, makes any warranty, express or implied, or assumes any legal liability or responsibility for the accuracy, completeness, or usefulness of any information, apparatus, product, or process disclosed, or represents that its use would not infringe privately owned rights. Reference herein to any specific commercial product, process, or service by trade name, trademark, manufacturer, or otherwise does not necessarily constitute or imply its endorsement, recommendation, or favoring by the United States Government or any agency thereof. The views and opinions of authors expressed herein do not necessarily state or reflect those of the United States Government or any agency thereof. 


\section{DISCLAIMER}

Portions of this document may be illegible in electronic image products. Images are produced from the best available original document. 
Issued by Sandia Laboratories, operated for the United States Energy Research \& Development Administration by Sandia Corporation.

\section{NOTICE}

This report was prepared as an account of work sponsored by the United States Government. Neither the United States nor the United States Energy Research \& Development Adminis. tration, nor any of their employees, nor any of their con. tractors, subcontractors, or their employees, makes any warranty, express or implied, or assumes any legal liability or responsibility for the accuracy, completeness or usefulness of any information, apparatus, product or process disclosed, or represents that its use would not infringe privately owned rights. 


\title{
SAND77-0368 \\ UNLIMITED RELEASE \\ Printed APRIL 1977 \\ SUBSTRATE CLEANING PRIOR TO THICK FILM SCREENING
}

\author{
G. J. HoF \\ DIVISION 2152 \\ Sandia Laboratories \\ ALBUQUERQUE, NM 87115
}

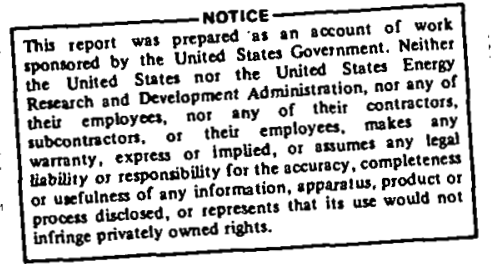

\section{ABSTRACT}

Cleaning requirements for thick film screening are. not as critical as for thin film application. Seven different prescreen preparations from no cleaning at all to the rigorous cleaning required for thin film were studied. The results show very little difference in thick film to substrate adhesion strengths for the different preparation methods. From the practical standpoint that some preparation is necessary to compensate for manufacturing or storage variables a minimum cleaning prior to thick film screening. is recommended.

Printed in the United States of America Available from:

National Technical. Information Service U. S. Department of Commerce 5285 Port Royal Road Springfield, VA 22161

Price: Rer copy \$4.50Micrafie $\$ 225$ 


\section{SUBSTRATE CLEANING PRIOR TO THICK FILM SCREENING}

\section{INTRODUCTION}

Substrate surface cleanliness requirements prior to thick film screening were known to be less critical than surface cleanliness requirements prior to sputtering or vacuum deposition of thin film. Preliminary investigation which involved phone calls to other manufacturers of thick film microcircuits indicated that substrate preparation ranged from no cleaning, as practiced by one manufacturer, to careful cleaning being required by others. Cleaning in organic solvents and detergent solutions with ultrasonic agitation plus deionized water rinses were considered careful cleaning procedures.

For our own thick film applications at Sandia it was considered appropriate to evaluate the effect that different cleaning pronedures or no cleaning at all might have on adhesion strength of a thick film conductor ink to substrate surfaces. The objective, if it could be determined, was to propose a cleaning requirement that would be consistent with good thick film to substrate adhesion strength, and minimum cost.

\section{Procedure}

Figure 1 is a graphic outline of the investigation. The seven different substrate surface conditions ranged from the No. 3 condition which involved rigorous cleaning currently required prior to sputtering for thin film to no cleaning at all such as No. 4 and No. 5 where the substrates went directly from the shipping package to thick film screening.

The No. 1 method of cleaning, as referred to herein, had been proposed as part of the effort to reduce the usage of trichloroethylene and acetone. Trichloroethylene is by definition photochemically. reactive and therefore has restrictive limits on 1ts use imposed by the Occupational Safety and Health Act of 1970 (OSHA) and the Clean Air Act of 1970 as implemented by the Environmental Protection Agency (EPA). Although acetone is not restricted on this basis, it was, nevertheless, also considered in the reduction of solvent usage. 


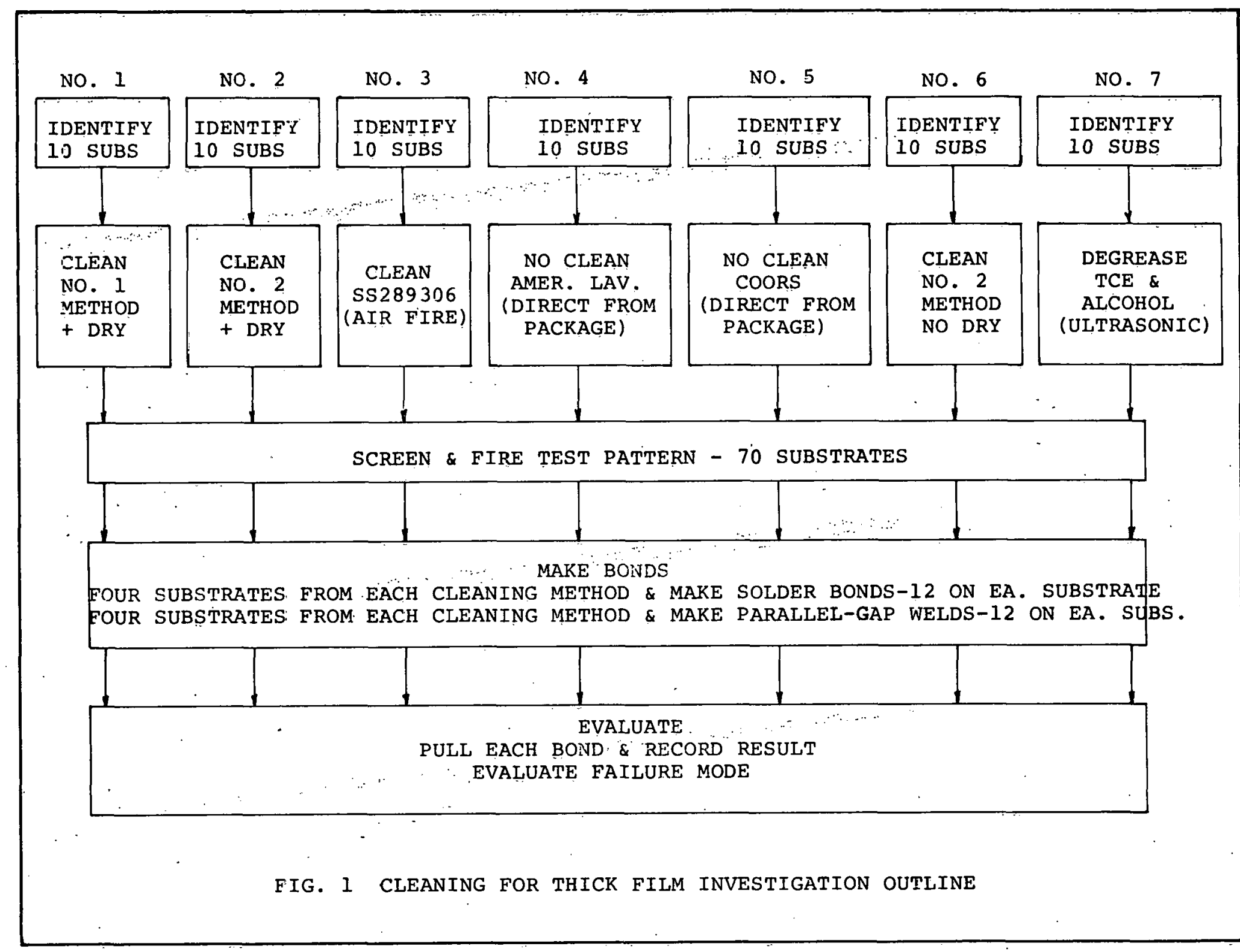


In the following outline of the No. 1 method of cleaning, the cleaning solution described in step 1 had been recommended by $L$. $K$. Jones, and others. 1

1. Submerge substrates in a solution of $78.8 \%$ by volume isopropyl alcohol, $20 \%$ by volume deionized water, and 0.28 by volume Igepal co-710 and agitate in ultrasonic cleaner for 2 minutes minimum.

2. Rinse in deionized water for 2 minutes minimum also by agitation in the utrasonic cleaner.

3. Rinse in transistor (cascade) washer, water at $80^{\circ} \mathrm{C}$ minimum and resistivity at 10 megohms per $\mathrm{cm}$ minimum, 5-ctep rinse, 2 minutes each.

4. Blow dry using dry nitrogen gas.

5. Air dry for 30 minutes minimum in a clean oven at $150^{\circ} \mathrm{C}$ minimum. (We used the air fire oven at $900^{\circ} \mathrm{C}$ for 15 minutes.)

The No. 2 method of cleaning, as referred to herein, consisted of the currently used procedure per SS289306 required for thin film sputtering, except that trichloroethylene and acetone are again deleted, in the interest of reducing usage of these two solvents for reasons discussed previously. The procedure is outlined as follows:

1. Submerge substrates in a solution of one liter of deionized water and $2 \mathrm{ml}$ of Igepal $\mathrm{CO}-710$ and agitate in an ultrasonic cleaner for 2 minutes minimum.

2. Rinse in deionized water for 2 minutes minimum also by agitation in the ultrasonic cleaner.

3.: Rinse in transistor (cascade) washer, water at $80^{\circ} \mathrm{C}$ minimum and resistivity, at $10^{\circ}$ megohms per $\mathrm{cm}$ minimum, 5-step rinse, 2 minutes each.

4.: Blow dry using dry nitrogen gas.

5. Air dry for 30 minutes minimum in a clean oven at $150^{\circ} \mathrm{C}$ minlmum. (We used the air fire oven at $900^{\circ} \mathrm{C}$ for 15 minutes.) 
The procedure identified as No. 3 in Figure 1, per the currently used ss289306 prior to sputtering, is as follows:

1. Submerge substrates in trichloroethylene and agitate in ultrasonic cleaner for 2 minutes minimum.

2. Submerge substrates in acetone and repeat step 1 .

3. Submerge substrates in a solution of one liter of deionized water and $2 \mathrm{ml}$ of Igepal co-710 and repeat step 1 .

4. Submerge substrates in deionized water and repeat step 1 .

5. Rinse in transistor (cascade) washer at $80^{\circ} \mathrm{C}$ minimum and resistivity at 10 megohms per $\mathrm{cm}$ minimum, 5-step rinse,' 2 minutes each: :.

6. Blow dry using dry nitrogen gas.

7. Fire in air at $860^{\circ} \mathrm{C}$ minimum for one hour minimum.

The No. 6 cleaning method (see Figure 1) was considered for the effect of deleting the air dry in the No. 2 method. The No. 7 cleaning method had been successfully used for other studies and was included for comparison.

The substrates were $96 \%$ alumina $\left(\mathrm{Al}_{2} \mathrm{O}_{3}\right), 25.4 \mathrm{~mm}$ square, and $0.635 \mathrm{~mm}$ thick. American Lava substrates were used except those identified with the No. 5 condition which were Coors. High purity (99.5\%) alumina substrates provided unacceptable results which are discussed later in this report.

The thick film ink was Cermalioy No. 4120 PtAu conductor, chosen because in previous work it had demonstrated good adhesion.

The test pattern used, see Fiyuie. 2 , was onc that was propnsed as a standard for the industry by the E. I. DuPont De Nemours \& Co. Inc., 2 except that provision was made for $12 ; 2-\mathrm{mm}$ square pads instead of 9 as proposed by DuPont. Eight substrates were used from each preparation method, four for parallel gap welding, and four for soldering. Thus, 96 burls lotal werc toctod for earh method of cleaning preparation.

A minimum of time was allowed to lapse between cleaning of substrates, thick film screening and firing, cleaning prior to bonding, and application of bonds. Actually, screening and firing occurred within a day after cleaning (five different techniques) and bonds were 


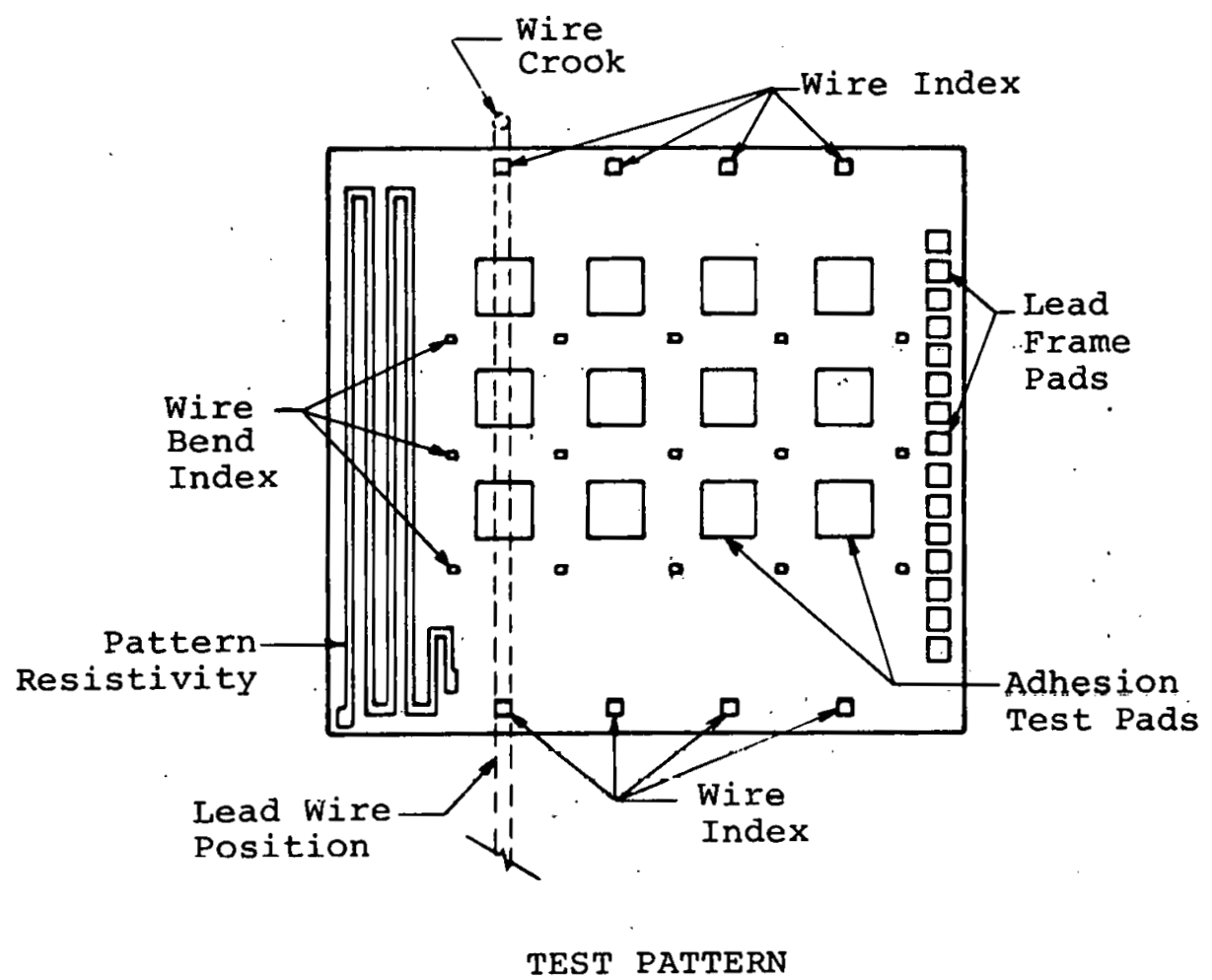

Figure 2

made within three days of the cleaning process per SS289358, normally done before bonding. This prebond cleaning procedure was as follows:

1. Submerge parts in boiling trichloroethylene for 10 minutes.

2. Manualiy rinse pares in room temperature alcohol for 10 seconds.

3. Submerge parts in boiling detergent solution consisting of $2 \mathrm{ml}$ of Igepal. co710 per liter of deionized water for 10 minutes.

4. Manually rinse parts in room temperature deionized water for 10 seconds.

5. Rinse in transistor (cagoade) waehcr, watcr at $80^{\circ} \mathrm{C}$ minimum and resistivity at 10 megohms per $\mathrm{cm}$ minimum, 5-step rinse, 2 minutes each.

6. Blow dry using dry nitrogen gas.

As was indicated previously, the test pattern was adopted from a proposed industry standard ${ }^{2}$ for adhesion testing of thick film using 
solder joints. However, since parallel gap welds using gold ribbon also make strong bonds to thick film, this was considered another good test of thick film adhesion to substrate. The essential requirements of the proposed standard ${ }^{2}$ for testing thick film adhesion using solder joints are as follows:

1. Wire soldered to the test pads was AWG No. 20 tinned copper bus wire.

2. Solder was $63 / 37, \mathrm{SnPb}$, and flux was Alpha 611 (mildly activated).

3. One end of each wire was shaped into a crook to provide a means of self-clamping the wire to the substrate.

4. Wires were centered across the test pads by means of the indexing (see Figure 2). Each wire crossed three test pads thereby making three solder joints. Four wires clipped to each substrate pattern made a total of 12 joints.

5. Solder bath temperature was maintained at 250 to $255^{\circ} \mathrm{C}$.

6. Each substrate with wires in place was immersed in the solder pot for 8 to 10 seconds and withdrawal rate was approximately $12 \mathrm{~mm}$ per second.

7. Solder bonds were allowed to cool in still air and were aged for 16 hours before tensile-peel testing.

Tensile-peel testing of solder bonds was done on an Instron tester. Crosshead speed was $12.7 \mathrm{~mm}$ per minute. Wires were bent to a perpendicular position with the substrate surface at a point $1: 27 . \mathrm{mm}$ from the test pad leading edges prior to tensile-peel testing. Crosshead motion was arrested inumiately aftcr, bond failure to minimize bending effect of the wire on the next pad. Tensile-peel strength readout was on a strip-chart recorder with full-scale readout of $4.54 \mathrm{~kg}$.

Gold ribbon $0.05 \mathrm{~mm}$ thick by $0.37 \mathrm{~mm}$ wide was used for the parallel-gap welds to the test substrate pads. Ribbon pieces approximately $19 \mathrm{~mm}$ long to allow sufficient length for gripping in the tensile tester. were parallel-gap welded at one end to the test pads. As has been indicated before, there were 12 test pads, consequently, there were 12 ribbon bonds on each substrate. Welds were made at 0.55 volt, 400 milliseconds, with electrode pressure of $1.8 \mathrm{~kg}$ and with a $0.127 \mathrm{~mm}$ gap between electrodes. 
Tensile-peel testing of parallel-gap welds was also done on an Instron tester. Crosshead speed was $25.4 \mathrm{~mm}$ per minute. Tensile-peel strength readout was on a strip-chart recorder with full-scale readout of $0.5 \mathrm{~kg}$.

\section{RESULTS}

This study was done twice. In the first study all substrates were of the 99.58 alumina $\left(\mathrm{Al}_{2} \mathrm{O}_{3}\right)$ purity. There was, at this time, no knowledge of a possible difference in thick film to substrate adhesion strength between $99.5 \%$ purity and $96 \%$ purity alumina substrates. The result, however, was that thick-film-to-substrate adhesion strengthe tested with soldex joints were virtually zero. Parallel-gap weld tests were somewhat better but not adequate. Visual comparison revealed that Cermalloy 4120 thick film on 99.58 alumina had a yellowish-green color not evident on thick film on $96 \%$ alumina substrates. An interim study ${ }^{3}$ comparing two manufacturers; two inks, and $96 \%$ and $99.58 \mathrm{Al}_{2} \mathrm{O}_{3}$ substrates revealed significant differences and the $96 \%$ purity most suitable for thick film application.

In performing the second study, using the 968 alumina substrates, there was an anomaly in the data that requires an explanation. One of the substrates that.received No. I cleaning, had, as a substrate, abnormally low adhesion strengths. This particular substrate was examined visually under magnification and backlighting and, in addition, thick film thickness was measured. This revealed that the film had greater porosity than normal and was thinner than normal by about $32 z$. This cunflrmed what was already known; that thinner films have lower adhesion to substrate strength. Why this particular test pattern had thinner film is not known. Data for this report is from an extra substrate from the original lot that was cleaned, screened, and fired for this study. It was separately parallel-gap welded using the same weld parameters as had been previously used.

The extent and care in cleaning, or not cleaning at ali; prior to thick film screening and firing had less effcct on adhesion strenyth to the substrate than anticipated. For the comparative effect on parallel-gap welds a bar chart is shown in Figure 3. Note that the average tensile-peel strengths were all nearly the same. Standard deviation was less for the No. 1 CLEAN, but it is not known that this is significant. FULL CLEANING for sputtering (No. 3) per ss289306 was expected to provide superior adhesion, but was no better than for those substrates that received no cleaning at all. 
FIGURE 3

PARALLEL-GAP WELDS

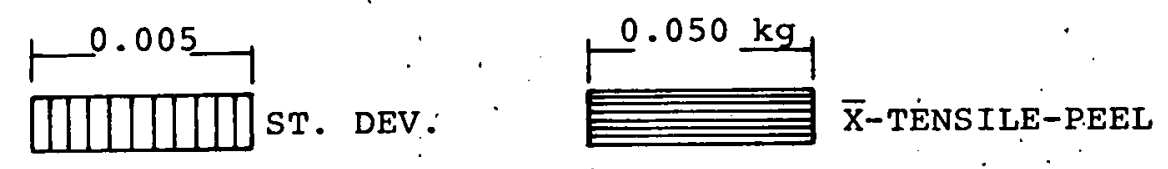

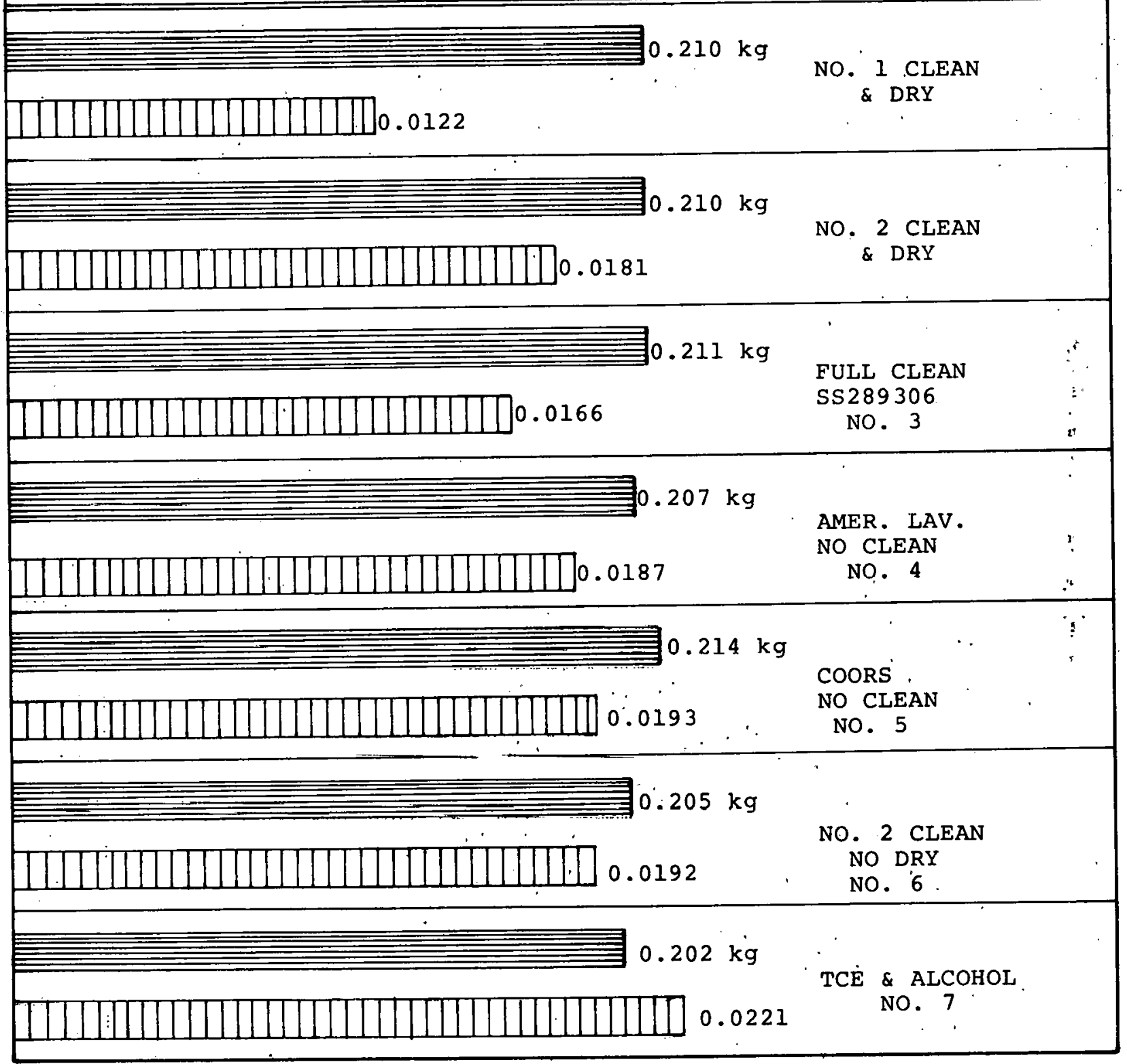


Figure 4 shows TENSILE-PEEL and STANDARD DEVIATION results using solder joints. Again, the average adhesion strengths were nearly the same for all prescreening conditions except that in the case of FULL CLEAN (NO. 3) per SS289306 TENSILE-PEEL strengths were somewhat less and STANDARD DEVIATION was the worst. Again, it had been expected that the most rigorous cleaning would result in the best film to substrate adhesion. Both American Lava and Coors without cleaning had good adhesion strengths and favorable STANDARD DEVIATION.

Figures 5 and 6 show tallied frequency of adhesion strengths within selected intervals from minimum to maximum adhesion strengths. Whether it is significant or not, the No. 1 cleaning had no failures below the mid range.

All failures of solder joints were in the thick film th substrate adhesion. Failures on all substrates in the parallel gap welds were both in the thick film to substrate adhesion and in ribbon breaks.

Finally, D. D. Sheldon ${ }^{4}$ made a statistical analysis of the data derived from this study and concluded that a preferred method of cleaning for thick film application is not evident.

\section{RECOMMENDATION}

Considering that this study showed no clear choice of substrate cleaning preparation for thick film screening, a recommendation requires some practical considerations. With no cleaning there is over the long run no control of substrate surface conditions prior to screening although in this study lack of cleaning had no serious effect on adhesion strengths. Consideration must be made for manufacturing or storage variables; therefore, a prescreen cleaning is desirable. The No. 2 proposed cleaning is the most economical and materials are readily available and not toxic. However; the procedure can only be considered effective on inorganic contaminants. The No. 1 proposed cleaning, by using alcohol, should be effective on both organic or inorganic contaminants and therefore should be considered a more reliable cleaning method. 
FIGURE 4

SOLDER JOINTS

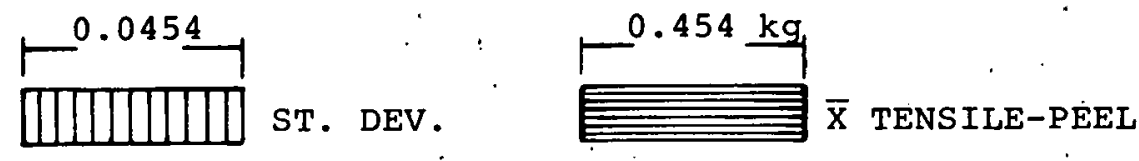

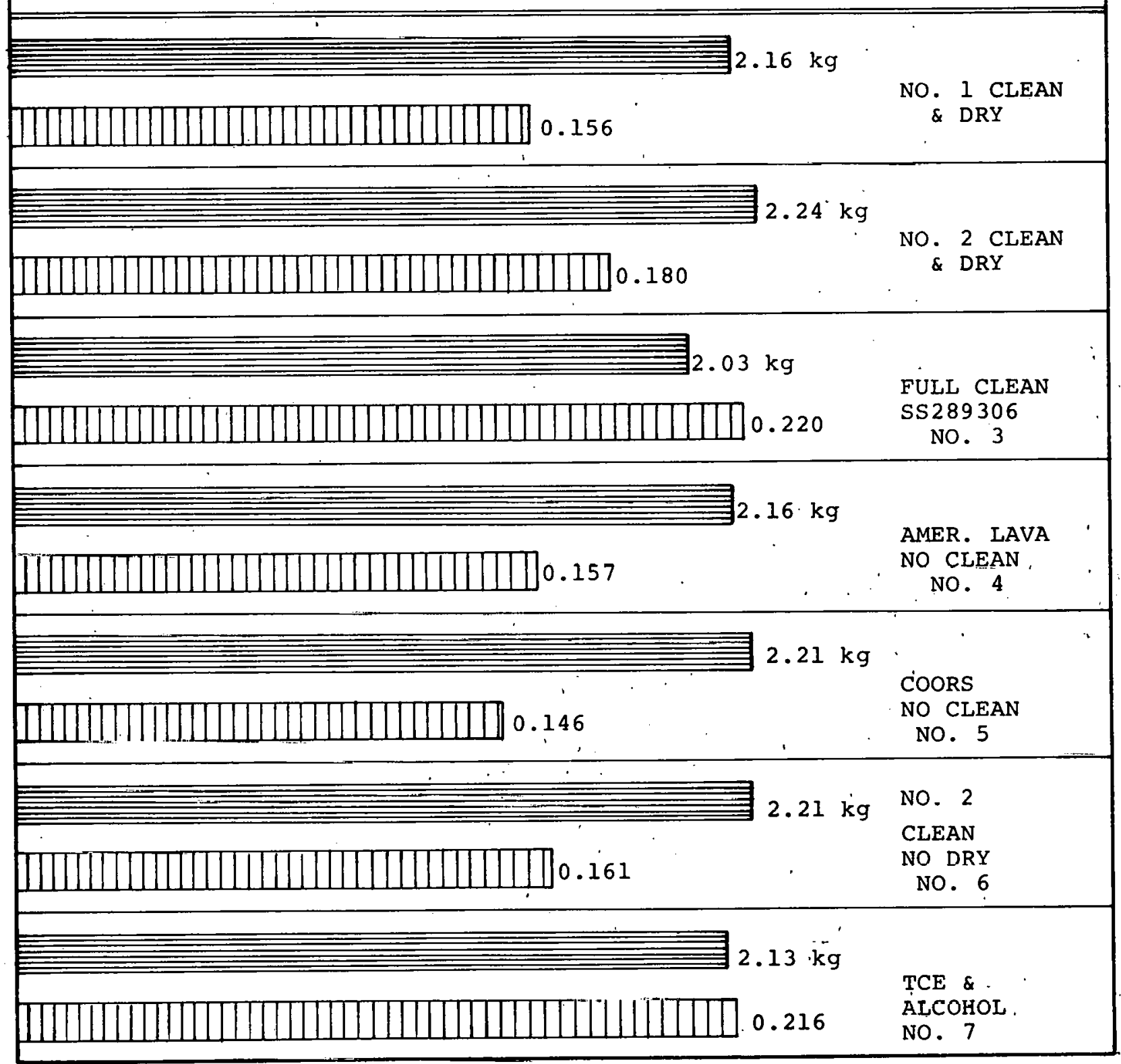


ADHESION STRENGTH INTERVALS - $\mathrm{kg}$

\begin{tabular}{|c|c|c|c|c|c|}
\hline $\begin{array}{l}\text { Cleaning } \\
\text { No. }\end{array}$ & $.125-.149$ & $.150-.174$ & $.175-.199$ & $.200-.224$ & $.225-.249$ \\
\hline No. 1 & & & HH III & $\begin{array}{l}\text { HHHH HA } \\
\text { HHHH HH } \\
\mathrm{IIJ}\end{array}$ & HHI \\
\hline No. 2 & I & \% & HH & $\begin{array}{l}\text { HH HH HH } \\
\text { HH HH HH } \\
\mathrm{I}\end{array}$ & HAIIII \\
\hline No. 3 & & $/ /$ & HHI & $\begin{array}{l}\text { HHHH HH } \\
\mathrm{HHHH} H\end{array}$ & HA III \\
\hline No. 4 & & /II & HHAHI & $\begin{array}{l}\text { HH HH HH } \\
\text { HH HA III }\end{array}$ & HH \\
\hline $\mathrm{N} \cap=5$ & I & I & HA & $\begin{array}{l}\text { HH HH HA } \\
\text { HH HAIII }\end{array}$ & HH HA IIII \\
\hline No. E & I & III & HII III & 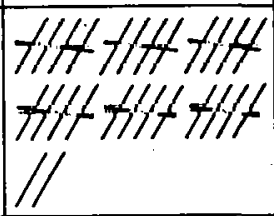 & IIII \\
\hline No. 7 & $/ / 1$ & // & HHA THIII & $\begin{array}{l}\text {-HH HAH HH } \\
\text { HH HH. }\end{array}$ & HHI \\
\hline
\end{tabular}

FIGURE 5 TALLIED FREQUENCY ADHESION STRENGTH VS FREQUENCY

PARALLEL-GAP WELDS 
ADHESION STRENGTH INTERVALS - $\mathrm{kg}$

\begin{tabular}{|c|c|c|c|c|c|}
\hline${ }^{C l}$ paning & $1.360-1.587$ & $1.588-1.813$ & $1.814-2.040$ & $2.041-2.267$ & $2.268 \div+$ \\
\hline No. 1 & & & HH HHI & $\begin{array}{l}\text { HH HH HH } \\
\text { HH HH II }\end{array}$ & HAH HA \\
\hline No. 2 & & & HHI & $\begin{array}{l}\text { HH HH HH } \\
\text { HH }\end{array}$ & $\begin{array}{l}\text { HH HH HH } \\
\text { HH I }\end{array}$ \\
\hline No. 3 & $/ /$ & $/ / I$ & $\begin{array}{l}\text { HH HH HH } \\
\mathrm{II}\end{array}$ & $\begin{array}{l}\text { HH HH HH } \\
/ I\end{array}$ & HAII \\
\hline No. 4 & & 1 & HA III & $\begin{array}{l}\text { HH HH HA } \\
\text { HH HHI }\end{array}$ & HH HA III \\
\hline No. 5 & & & HAI & $\begin{array}{l}\text { HH HH HH } \\
\text { HH HH }\end{array}$ & $\begin{array}{l}\text { HH HH HH } \\
/ /\end{array}$ \\
\hline No. 6 & & . & HH III & $\begin{array}{l}\text { HH HH HH } \\
\text { HH II }\end{array}$ & $\begin{array}{l}\text { HH HH HH } \\
\mathrm{ll}\end{array}$ \\
\hline No. 7 & 1 & $/ I I$ & HAII & $\begin{array}{l}\text { HH HH HH } \\
\text { HH III }\end{array}$ & HH HH II \\
\hline
\end{tabular}

FIGURE 6 TALLIED FREQUENCY

ADHÉSION STRENGTH VS FREQUENCY

SOLDER-JOINTS 


\section{REFERENCES}

1. SC-DC-66-1118, January 1969, Clean Assembly Practices Guide, L. K. Jones, 5821, et.al.

2. Method of Test for Wire Peel Adhesion of Soldered Thick Film Conductors to Ceramic Substrates, E. I. DuPont De Nemours \& Co., Inc., Electrochemicals Dept., Wilmington, DE 19898. Reprinted from DuPont Product Catalog by State of the Art, Inc., 1973.

3. The Influence of Substrate Purity and Manufacturer on Thick Film Conductor Adhesion, by D. R. Johnson and G. J. Hof, presented as a paper by D. R. Johnson at the American Electroplators' Society, Inc., Design and Finishing of Printed Wiring and Hybrid Circuits Symposium, at the Fort Worth Hilton Inn, Fort Worth, Texas, January 21-22, 1976. Technical report to be published.

4. Memo, Evaluation of Substrate Cleaning Methods, D. D. Sheldon, 1223 , to $G$. J. Mof, 2152, daled November 12, 1975: 


\begin{tabular}{lll}
\multicolumn{3}{l}{ DISTRIBUTION: } \\
BKC & J. S. Bosnak & D842 \\
BKC & A. O. Bendure & D842 \\
BKC & N. C. Thomas & D842 \\
1223 & D. D. Sheldon \\
2150 & C. M. Tapp \\
2151 & R. C. Heckman \\
2152 & J. T. Grissom \\
2152 & R. E. Knutson \\
2152 & F. Uribe \\
2152 & G. J. Hof (10) \\
5821 & L. K. Jones \\
5821 & F. W. Oswalt \\
8266 & E. A. Aas (2) \\
3141 & Library (5) \\
3151 & W. L. Garner (3) \\
$3171-1$ & R. P. Cam \\
\multicolumn{4}{l}{ ERDA/TIC (25) }
\end{tabular}

